bishop who found himself storm-driven on the Galapagos. Implicit in the whole book is the conservation message, though Dr Dorst does not labour the point; indeed sometimes he seems a little optimistic: does the vicuña still 'abound' in the altiplano of Peru, and are lobsters still 'plentiful' in the Galapagos?

The photographs are numerous - one or two to every opening and all good, many of them breathtakingly so, whether in black and white or colour (though the blockmaker let his imagination run riot with a Galapagos land iguana which is the colour of a berobed Father Christmas). Magnificent views of mountain and forest, rivers and deserts and splendid portraits of the wildlife that inhabit them, they are a superb adornment and portrayal of an outstanding text.

MAISIE FITTER

\title{
Bwana Game by George Adamson. Collins and Harvill, $35 \mathrm{s.}$
}

Of the people who get taken on the national park round from Nairobi and, from the comfort and safety of their vehicles, see all those marvellously cared-for animals living in a terrestrial paradise, how many suspect that there may be somewhere some other sort of wilderness Africa? For there certainly is; and if they want to see it they should venture into the less law-abiding parts of Kenya that stretch away into the north and east towards Ethiopia and Somalia. Failing that they should read George Adamson's book (nearly 300 pages and many fine photographs) for a picture of what things are like up there. Or perhaps I should say were like up there, for his narrative extends back to his early days when he set out to prospect for gold and trade in skins. When these ventures came to nothing he took up game wardening, a job which gave him everything he wanted - travel, adventure, danger, a rough existence and, above all, close contact with wild life. All safaris were on foot, and his journeys were long tests of endurance. For years his job was largely a matter of rounding up poachers or killing rogue elephants and man-eating lions. The killing of these fine animals which innocently blundered into conflict with over-populous humanity makes especially sad reading because you know that Adamson's deepest sympathies are with the animals. But worse was to come.

It was wartime and the authorities had decided to eliminate large numbers of game animals in a district where they were alleged to be competing for food with domestic stock. It was George Adamson's job to kill as many zebra and oryx as he could, and we get this significant sentence: 'A dreadful aspect of the slaughter was that while engaged in the actual shooting I observed that I unconsciously developed a ruthless blood-lust'. It is a confession that should be noted by all who start killing animals for whatever reason - even for conservation or science.

When he got married George Adamson's way of life hardly altered because Joy was also adventurous and addicted to tough safaris. Then into their lives came Elsa. If you have read Joy Adamson's three Elsa books you may quail a little, but George brings in quite new facets of the remarkable man-womanlion story. In fact it becomes more a man-lion story with Joy not mentioned overmuch. He tells the story of how the film was made and, more important, of how he then took to the bush with three of the film lions in order to rehabilitate them to life in the wild. Soon he was given four cubs to add to the party and so he settled to a completely lion-addicted but otherwise solitary existence in the centre of the Meru Game Reserve. The book ends with him still there among the lions. 'It is my hope', he says 'that I may be permitted to continue my association with them indefinitely ...' Good luck to the fellow, he deserves it. So does his very readable book. 